ENCYCLOPEEDE Encyclopédie berbère

BERBERE

27 | 2005

27 | Kairouan - Kifan Bel-Ghomari

\title{
Kef el-Kerma
}

G. Souville

\section{(2) OpenEdition}

Journals

Édition électronique

URL : http://journals.openedition.org/encyclopedieberbere/1329

DOI : 10.4000/encyclopedieberbere.1329

ISSN : 2262-7197

\section{Éditeur}

Peeters Publishers

\section{Édition imprimée}

Date de publication : 1 août 2005

Pagination : 4131-4132

ISBN : 2-7449-0538-0

ISSN : 1015-7344

\section{Référence électronique}

G. Souville, «Kef el-Kerma », Encyclopédie berbère [En ligne], 27 | 2005, document K36, mis en ligne le

01 juin 2011, consulté le 24 septembre 2020. URL : http://journals.openedition.org/

encyclopedieberbere/1329; DOI : https://doi.org/10.4000/encyclopedieberbere.1329

Ce document a été généré automatiquement le 24 septembre 2020

(c) Tous droits réservés 


\section{Kef el-Kerma}

\section{G. Souville}

1 Abri sous roche situé dans la région d'El Hank - Sidi Abderrahman, sur la route côtière Casablanca-El Jadida (Mazagan), en bordure de l'ancien champ de tir de Kef el Harroun. Dans les publications anciennes, il est souvent désigné sous le nom « d'abri du champ de tir ». Cet abri s'ouvre à $4 \mathrm{~m}$ de haut. Il est intéressant par ses gravures rupestres, des sondages et des fouilles déjà anciens n'ayant livré que des traces de foyers avec des débris de coquilles marines.

2 Les gravures peuvent se regrouper en deux ensembles; l'inférieur montre des cupules et des sortes de rigoles. Une table horizontale est ornée de cupules espacées. Face à la mer, une paroi verticale porte un personnage sommairement dessiné : le corps est représenté par un rectangle; les membres sont indiqués par des traits verticaux en prolongement des côtés latéraux du rectangle. Les mains semblent mieux dessinées que les pieds, la main gauche étant largement étalée. 
Le personnage de Kef el-Kerma.

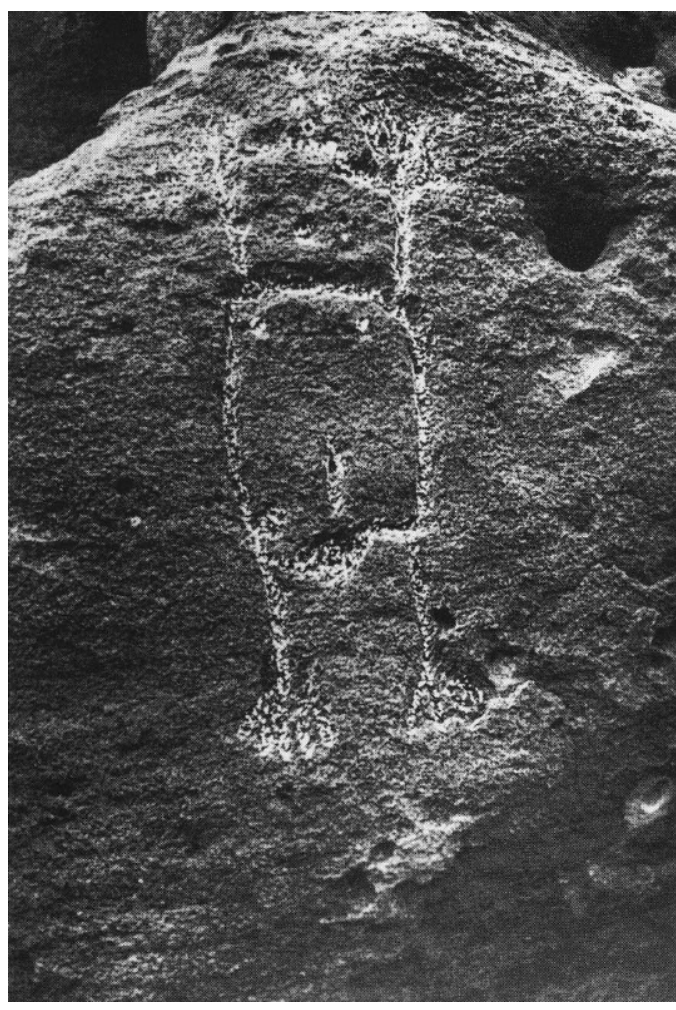

Des traits doivent correspondre à la bouche, aux seins et à l'ombilic de ce personnage ithyphallique. Le panneau supérieur est orné de cercles, de rectangles accolés, d'une vingtaine de petites cupules et d'une série de rigoles. Un personnage y figure également, comparable au précédent mais plus sommairement dessiné. Les gravures rupestres sont exceptionnelles au Maroc atlantique.

\section{BIBLIOGRAPHIE}

ANTOINE M., 1935. « Notes de préhistoire marocaine, 10. Les pétroglyphes de l'abri du champ de tir, près de Casablanca », Bull. Soc. Préhist. Maroc, t. 9, p. 67-78, 9 figures.

SOUVILLE G, 1973. Atlas préhistorique du Maroc, 1. Le Maroc atlantique, Paris, CNRS (coll. Études d'Antiquités africaines), p. 184-187, figures 89-91.

\section{INDEX}

Mots-clés : Art rupestre, Maroc, Protohistoire 